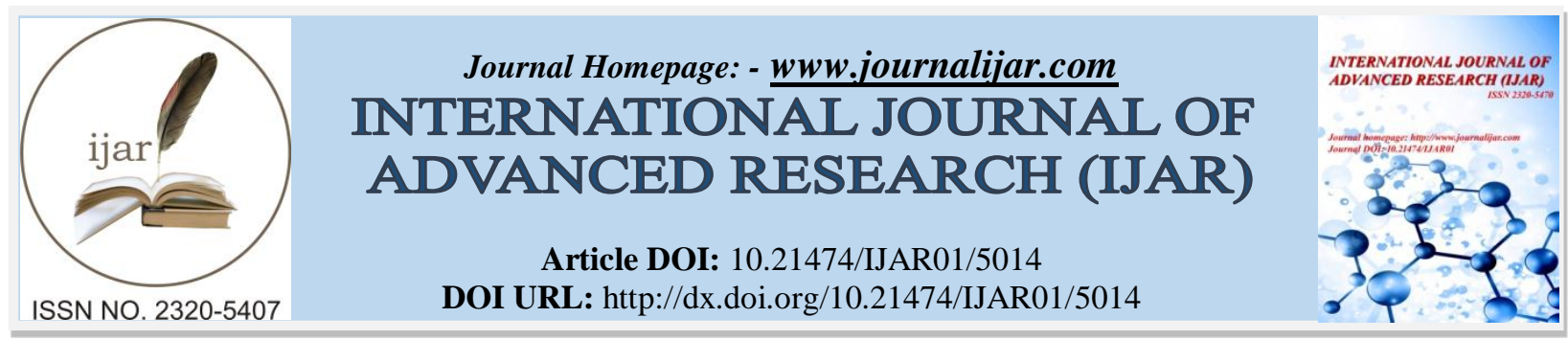

RESEARCH ARTICLE

\title{
VESTIGIAL PRACTICES OF TANTRIC TRADITION: AN ANALYSIS OF YOGA AND ITS SURVIVAL.
}

Nilam Kakati.

Ph.D. Research Scholar Department of History University of Hyderabad India.

\section{Manuscript Info}

Manuscript History

Received: 28 May 2017

Final Accepted: 30 June 2017

Published: July 2017

Key words:-

Tantra, Yoga, Tantric Yoga, sexual union, popular culture.
Abstract

Tantra, the misunderstood Indic religious tradition had been a topic of fascination for both western and Indian scholars. Albeit comprised of a vast domain of rituals and practices, it has frequently been viewed through the lens of left- handed practices. Yoga comprised one of the vestigial practices in Tantric tradition. The article makes an attempt to examine the crux of tantric yoga, its commercialization like workshops, events and survival in popular culture by collaborating it with sexual union. Tantric yoga comprises a philosophical sphere including body and mind and does not limit itself to sexual perspective. To embrace and blend with popular culture habitually the philosophical sphere is left aside. The article also makes an attempt to identify the roots of misrepresentation of Tantra. Esoteric nature of Tantra does not give away the precise meaning of its tradition and thus it is often misrepresented. This augments a flawed understanding, which could be erased by undertaking an extensive study of the same.

Copy Right, IJAR, 2017,. All rights reserved.

\section{Introduction:-}

'Tantra' is one of the religious sect which is invariably encircled by perplexity and argumentation. The origin of Tantra itself is encircled in debate and discussion. Theory concerning origin of Tantra has been divided into two sections. Scholars like Lalan Prasad Singh, M. C. Joshi, and David White debates in support of Indian origin of Tantra and Scholars like H. P. Sastri, debate in support of foreign origin of Tantra. The suggestions put forward by both group of scholars cannot be recognized as authentic, however by scrutinizing the evidences minutely, partially it can be supposed that Tantra had its origin in India itself and then had spread to other parts of the World. The subsequent debate regarding Tantra is to label it as a religious sect or movement? The term movement would be more apt for Tantra. The term tradition can also be used to describe Tantra.

Banerji views the commencement of Tantra as "Tantras were a set of scriptures, which arose as a protest against those scriptures which insisted on self- mortification and austerities etc. as means to the attainment of emancipation of the soul from the bondage of rebirths.'(Banerji, 2007) 'Tantra can be considered to be a class of literature which does not follow the conventional or traditional Veda based Brahmanical scriptures like Dharmasutra, Dharma Sastra, etc."(Banerji, 2007)

N. N. Bhattacharyya also shares his views "The etymological interpretations point to the fact that Tantra was a general term for any system serving as the guiding principle of any work and that the use of the word in a strictly 
religious sense was a later growth.”(Bhattacharya, 1982) “... As many as an entire half of the Saivite religious were, in fact, characterized by the cult of an androgynous or female divinity. These cults appeared to have become complicated with ritual observances either of a horrible or of an obscure nature, which must have led to their being relegated to a special literature of occult character - the Tantras."(Bhattacharya, 1982)

Consequently Tantra had flourished far and wide. Both favorable and unfavorable facts had promoted it. Favorable facts like the inclusion of women and sudras under its umbrella and unfavorable facts like the affiliation of Tantra with sex, magic, sacrifice etc. which were outside the realm of mainstream Indic religious practices. However it cannot be denied that both the facts have contributed in its unique ways for flourishing of Tantra.

Utmost misfortune of Tantra is that it is frequently amalgamated with aspects like sex, magic and sacrifice, which comes beneath left- handed practices. The purpose for this amalgamation can be assumed to be that these aspects draw more curiosity. Tantra is frequently referred through its left- handed practice rather than right- handed practices. But restraining Tantra only to one facet would do unfairness on its part. Tantra is comprised of a vast domain, and the article would like to highlight the other side of it. Vital aspect of Tantric tradition like yoga have been pushed to the background in contrast to these left- handed aspects. The article would try to examine these vital aspect of Tantra and its survival in the popular culture.

\section{Yoga in Tantric tradition:-}

Yoga, the ancient practice of meditation and wisdom comprises one of the vestigial practice that is followed in Tantra. It however did not had its origin within the frame of Tantra. The origin of yoga is a debatable subject and could not be established precisely. But the fact which cannot be overlooked is that, it was within the frontier of Tantra, yoga was commercialized. Yoga collaborated with Tantra received publicity and became a tool of amusement.

Yoga and Tantra both contributed each other in its enhancement. Yoga subsequently became allied with Hindu Tantra than Buddhist Tantra. "The Tantra arose out of and within the residual Yoga tradition of the time (third century C.E.) and as the collaboration between Yogacara and Tantra became more intense over the next few centuries, the persona of at least the Yogacara practitioners came to resemble more that of the Indian yogi then that of the Buddhist monk."(Soeng, 2010)

Yoga comprises a distinct and well established school in Indian philosophical thought but in union with Tantra, it is identified as Tantric Yoga, which is discrete in its way from the Indian philosophical yoga. Gavin Frost and Yvonne Frost bring forward the earliest evidence of tantric yoga, "In Pakistan, on the Indus River in the ancient city of Mohenjodaro, stands a monument bearing a golden seal, reliably as dated being 6000 years old. It depicts a person sitting in a Yoga posture performing a tantric ritual. This is the oldest evidence known of Tantric Yoga, the Royal path of sexual yoga, sometimes called the eight path."(Flood et al., 1989)

Kinsley is of the view that "Tantric yoga is supposed to awaken one's consciousness, to expand and intensify if. In classical yoga, the practitioner de-creates the various elements of prakrti, going against the natural rhythms of creation, in an attempt to still or transcend the limitations of the physical world. Classical yoga is the process of dissolving the creation in order to transcend it... Tantric yoga aims to unite the practitioner with the deity."'(Kinsley, 1998)

Feuerstein shares his view regarding Yoga in Tantra and Vedas. According to him "Tantra is a profoundly yogic tradition and the Tantras call themselves sadhana- shastras, or books of spiritual practices. The Sanskrit word Yoga means both 'discipline' and 'union' and can be translated as 'unitive discipline'. The oft- used compound Tantrayoga means simply 'Tantric discipline' and captures the intensely experiential character of the Tantric heritage. Tantra yoga is unitive discipline based on the expansion or unification of wisdom by means of the beliefs and practices promulgated in the Tantras and the exegetical literature that has crystallized around them... Tantra yoga as understood here, is a latecomer in the long history of yoga. As we have seen, however proto- Tantra elements can be detected even in the Vedic era. To be sure, the taproots of yoga are to be found in the Vedas, composed some five thousand years ago. In its most archaic form, yoga was a combination of ritual worship and meditation, having the purpose of opening the gates to the celestial realms and beyond."(Feuerstein, 1998) 
Witnessing yoga in cultural setting or religious setting is a debatable outlook. Albeit yoga has invariably been allied with religious traditions like Hinduism, Buddhism and Tantra, it constantly maintained its innate feature.

Tantric yoga unfurled an approach for creative uplift. However, for commercialization and exhibition purpose Tanta and yoga were bracketed with sexual union. This bracketing augments popularity and inquisitiveness of both Tantra and yoga, which eventually paves the path for its survival in popular culture.

\section{Tantric Yoga in popular culture:-}

Yoga being celebrated as a part of popular culture is not a matter of amusement but bracketing tantric yoga with sex for its survival to be a part of popular culture is not only a matter of amusement but also a misunderstanding of the whole process. The gap in understanding to an extent can be said to be deliberate. The said representation of tantric yoga have provided an impetus to commercialize yoga in western world.

Scholars have shared their view concerning this representation. White tires to give an example of survival of Tantric yoga in popular culture. He views it as "Both historically and conceptually, yoga is in many ways an internalization of sexual intercourse between a man and a woman [Hayes], which brings us back to the vexed matter of Tantric sex."(White, 2001)

Urban also says that Tantra yoga has become a part of popular culture through following the path of sex. He says "Yet for most contemporary New Age and popular writers, conversely, Tantra is now celebrated as a much-needed affirmation of physical pleasure and sexuality, as a "yoga of sex" or "cult of ecstasy" that might counteract the hypocritical prudery of the Christian West.”(Urban, 2010)

Gavin Frost and Yvonne Frost writes "There has been a general move among western writers to define in concrete mechanistic terms many ideas and concepts of Tantra- and indeed Yoga that are really indefinable. The whole Yoga movement was done a massive disservice when inexperienced translators made various spiritual centers or chakras synonymous with specific places in the body."(Flood et al., 1989)

However, few scholars have acknowledged the misrepresentation and tried to fill in the gap. "Tantra Yoga has been associated with sexual rituals in popular culture, but that is an inaccurate portrayal. Tantric thoughts assumes that we live in a dark age (Kali Yuga) and therefore must use every method possible to boost our spiritualty. Because Tantra yoga emphasizes the power of ritual, it has become most famous in Western culture for its notion that sexual energy is an important store of energy that can be rechanneled to further you along your to spiritual enlightenment. Our culture has expanded on the idea of sexual energy and sometimes perverts the concept into something it was never meant to be. Tantra isn't about sex. It is a complex, ancient and esoteric discipline with a wide range of practices, often involving sacred rituals based on the idea that humans are reflections of divinity."(Adamson et al., 1998)

Geoffrey, writes in appreciation of western scholars in the following words "Western societies have developed their understanding Asian religions, both popular and academic and these undoubtly have their own flaws and limitations. Critics of western academia often fail to appreciate the deep and positive engagement with Indic religions that underlies much 'orientalist' and more recent scholarship."(Geoffrey, 2008).

Geoffrey's views are acceptable to an extent. Western scholars try to engage in the understanding of Indic religions traditions in an appreciable measure. They take lot of pain to grasp the essence of Indic religious tradition. However when it comes to Tantra an inherent bias could be viewed in their understanding. Tantra is viewed frequently through the lens of sex. Fuss encircles around sexual rituals. This limited understanding of Tantra can be attributed to error in comprehending of Tantric texts and practices. Gavin Flood have accepted this error in his writings.

Misunderstanding of Tantric texts and practices does not limit itself with western scholars, but scholars of Indian origin also fail to grasp the inner meaning. Esoteric feature of Tantra limits its understanding. Tantric texts were written in a secret language, not revealing its true meaning. "Tantric texts are often composed in an "intentional language" (sandhya-bhasa), a secret, dark, ambiguous language in which a state of consciousness is expressed by an erotic term and the vocabulary of mythology or cosmology is charged with Hatha-yogic or sexual meanings."(White, 1970)

\section{Conclusion:-}

Tantra albeit one of the most misrepresented Indian religious traditions, have eventually survived, which is evident in popular cultures. Western and Indian scholars have made ample contribution towards it with writings including both the nature of advocacy and critiquing. Broad knowledge of Tantra depends on its depiction. But that is the 
tricky portion. As the language used in tantric texts are of an unrevealing nature, it is challenging to grasp the true meaning. Thus they are habitually misunderstood and thus misrepresented. This can be observed in both Western and Indian writings.

Collaborating tantric yoga with sex, impetus its recognition and transforms into a piece of commercialization. Brochures, workshops, events are organized to draw attention. This may augment the survival of tantric yoga in popular culture, however it does not present the complete image flawlessly. Flawless understanding of Tantra should be endeavored by scholars. Initiation of correct understanding could be noticed in the writing of contemporary scholars. But still an extended study has to be carried out to erase the misunderstanding regarding Tantric tradition and its practices.

\section{References:-}

1. Adamson, Eve and Budilovsky, Joan (1998) The Complete Idiot's Guide to Yoga, Alpha Books, p 54.

2. Banerji S. C. (2007) A companion to Tantra, Delhi, Abhinav Publications, p 7, p 11.

3. Bhattacharya N.N. (1982) History of the Tantric religion, Manohar Publishers \& Distributors, New Delhi, p 20, p 307.

4. Feuerstein, Georg (1998) Tantra: The Path of Ecstasy Shambhala Publications, London, p 18.

5. Frost, Gavin and Frost, Yvonne (1989) Tantric Yoga: The Royal Path to Raising Kundalini Power, Motilal Banarasidass Publishers, Pvt. Ltd, Delhi, p 3, p 8.

6. Geoffrey, Sameul (2008) The origin of Yoga and Tantra: Indic religions to the thirteenth Century, Cambridge University Press, p 10.

7. Kinsley, David R. (1998) Tantric Visions of the Divine Feminine: The Ten Mahavidyas, Motilal Banarasidass Publishers Pvt. Ltd., Delhi, p 57, 139.

8. Soeng Mu, (2010) Buddha and the Yogi: Paradigms of Restrain and Renunciation in Michael Stone (ed), Freeing the Body, Freeing the Mind: Writings on the Connections between Yoga and Buddhism, Shambhala Publications, London, p 126- 7.

9. Urban, Hugh B. (2010) The power of Tantra- Religion, Sexuality and the Politics of South Asian Studies, I.B.Tauris \& Co Ltd, London, $\mathrm{p} 1$.

10. White, David Gordon (ed), (2001) Tantra in Practice, Motilal Banarsidass Publishers Limited, Delhi, p 15.

11. Wright, Tenant C. (1970) Left Handed Hindu Tantrism Religious Studies, Cambridge University Press, Vol. 6, No. $4, \mathrm{p} 352$. 